\title{
The Architectural Foundation of New Urban Forms. The Case of Venice
}

\author{
MAURIZIO SABINI \\ Istituto Universitario di Architettura di Venezia \\ Italy
}

\begin{abstract}
Since the declining phase of the Modern Movement, the geography of disciplinary power has considerably changed and there has been an increasing loss of social significance for architecture. However, urban design, seen as a "mode" of architecture, rather than as a discipline in itself, has still a primary role to play against this trend, for there are instances and places where urban form, more than feasibility studies, or planning programmes, calls for attention. Such a new role for the discipline can be found in a new approach by which architecture is foremost seen as the art of environmental relations.

An interesting case-study in this regard can be the city of Venice, and particularly the areas of its latest (industrial) development, which are presently the focus of major rehabilitation projects. Some academic projects are used to show how voids and spaces are as important as buildings and volumes and that environmental relations among them, as well with the existing set-up, are founding elements of a new "urban form". What these designs try to demonstrate is the existence of an urban demand of form by the city which only architecture, through its "mode" of urban design, can properly address. A demand for a new, though fragmented and partial, "architecture of the city".
\end{abstract}

\section{INTRODUCTION}

The loss of social significance for architecture is a fact which is difficult to negate. What architecture was able to offer to society even until the age of the Modern Movement, that is a preminent system of arts and techniques capable of embodying a whole set of social and cultural aspirations, is not relevant any more. The physical representation of some social and cultural ideas centred on a certain general principle of economic and social emancipation for masses of people migrating from the countryside to the cities, from agricultural to industrial life, is not any more on the agenda. The task of giving quality to quantity is not any more a pressing social demand, for a minimum living standard has been already reached by large sections of society, at least in the more developed countries. The immense thrust of that social responsibility which has sustained the growth of the discipline from an almost exclusively academic technique into a socially relevant segment of knowledge during the Modern age, has come to an end.

In a world of increasing "immateriality" where work and life of people take place along the virtual paths of the information technology, the "heavy", concrete nature of architecture encounters great difficulties to find a place.

What before needed to be represented through built form finds new ways and means of celebration. The increasing sofistication and complexity of contemporary culture require more subtle, careful and complex interventions on our physical environment than simple buildings or set of buildings, no matter how "modern" (or "hyper-modern") they might appear or pretend to be. Also the very notion of "environmental responsibility" implied by the widely shared approach towards a "sustainable development" of our economies and settlements, not only in the less developed countries, but also and even more so in the more developed ones, load the discipline with an increasing set of technical and cultural requirements to be met by designs which have to enrich the environment with better systems of relations rather than a mere densification of the built systems. This means that society expects from architecture a contribution perhaps more humble, but not more simple (or less rewarding), about a better network of places, areas, "positions", in addition to buildings, as a framework for a better life in terms of quality of experience, psychological and emotional wellbeing.

\section{ARCHITECTURE AS THE ART OF ENVIRONMENTAL RELATIONS}

In this regard, architecture should address its very disciplinary status not simply in terms of the art of building (the technological sofistication of building systems already provide for a large part of it) rather than in terms of the art of environmental relations. Paraphrasing Louis I. Kahn, architecture is not simply any more about the "thoughtful making of space", rather "the thoughtful making of environmental relations". Relations between flexible systems of functions, between 
buildings themselves, between built and natural areas, between structure and meaning, between shelter and symbol, between voids and fabric within the "diffuse city", between places within the urban networks which tend otherwise to be more and more anonymous, uniform and indifferent.

Making reference to the theories by Niklas Luhmann ${ }^{1}$ on the systemic interpretation of the physical and social environment capable of guiding the government of complexity, and to the idea by Michel Foucalt ${ }^{2}$, by which in our time, space has assumed the form of relations between positions, Vittorio Gregotti tries to address the problem of architecture as a more complex task than simply space-making.

Assai più produttivo risulta invece interpretare l'idea che lo spazio abbia assunto la forma di rapporto tra posizioni qualora si accetti che $i$ concetti di posizione e relazione siano ridotti alla loro forma materiale e che proprio attraverso questa ci pervengano le informazioni su tutti gli altri significati. Ciò non significa la riduzione di ogni cosa a segno ma tentare di stringere un numero limitato, finito, di relazioni e posizioni nel quadro di un'organizzazione, cioè di una forma operabile; significa cioè immaginare la trasformazione ambientale come una serie successiva di configurazioni ognuna delle quali rigida. In qualche modo ritornare all' idea di spazio come insieme gerarchizzato di luoghi.3

In spite of the present diffusion of urban systems over very large areas of the physical environment and the consequent loss of traditional notions of "centre" and "periphery", of city and "non-city", the relationship between city and architecture, or between built systems and architecture is still an important and challenging question. Although contemporary life is less and less influenced by the specific physical places in which it happens, the built systems of our environment need the contribution of architecture to qualify the relations within them, to give meanings and roles to their different components (buildings, areas, paths, infrastructures), for an ever wider range of functions and users.

In our present condition of continuous urbanization (that is not continuous built systems, but certainly territories almost completely covered by plans and projects), architecture still (or more than ever before) retains a role of creating "occasions for experience". In other words (and again with Kahn): to suggest "wonder".

As it has been pointed out by Vittorio Gregotti:

Ogni operazione architettonica è sempre più azione di trasformazione parziale in situazione: riuso, restauro, ma anche nuovo e diverso in quanto messa in relazione contestuale di materiali presignificati. La stessa periferia urbana è luogo che cerca identità attraverso il consolidamento contestuale. Il progetto come modificazione è anche lo strumento operativo ragionevolmente praticabile quando si agisca sul paesaggio, per ciò che perdura di questo concetto, per mezzo di una strategia, per interventi discreti, per spostamenti minimi capaci di vasti cambiamenti di senso. ${ }^{4}$
This approach, widely shared by the architecture of the last decade, bears interesting and fruitful elements of disciplinary development from a theoretical point of view, even though we may not like the (non)figurative aesthetic choice (to follow a supposed "Modern orthodoxy") which often goes along with it.

\section{URBAN DESIGN AS A "MODE" OF ARCHITECTURE}

If regional and urban planning and programming play an increasingly important social role, with politicians, bureaucrats, investors, land economists and market analysts assuming heavier decision-making "specific weight"s, architecture maintains nevertheless the role of suggesting concrete visions, real hypotheses, and rational guidelines for meaningful transformations of our environment. Also, by its very nature of prefiguration of the world of tomorrow, in a way similar to a simulation game, architecture becomes a useful segment of knowledge in a world where simulation becomes the common approach for pondering decisions.

It is evident how in such a view of the disciplinary status, architecture tends to comprehend also the field and techniques of urban design. Or to put it better, how the urban designer mentality tends to permeate the architect's approach.

As it has been properly observed by Denise Scott Brown:

(...) the essence of the urban design approach is that it concentrates more on relations between objects, more on linkages, contexts and in between places, than on the objects themselves. It deals with long-time spans, incremental growth over time, decision-making that is complex and fractionated and relations between different levels and types of decision-making. Urban design is the subtle organisation of complexity, the orchestration of sometimes inharmonious instruments, the awareness that discord at a certain level can be resolved as harmony at another. (...) An urbanistic approach would inform my criticism of the partitions in an office space, a health systems plan, an economic development plan, or even the proportions of a teapot."

In this view, urban design ceases to be considered as a discipline on its own and becomes a sort of "mode" (maybe the most relevant one today) of architecture.

\section{THE CASE OF VENICE}

To test such an approach an interesting case-study is the city of Venice. This wonder city was founded and built on a most improbable building site: a group of sand islands in the middle of a lagoon where the uncertain balance between land and water had always created a rich, constantly changing, but also delicate and vulnerable natural environment ${ }^{7}$. From the Roman time to the Renaissance, architecture was able to cope with the conflicting demands of artificial order and natural systems, of representing human endeavour and al- 
lowing the many natural orders to follow their own course.

With the industrial age, a series of catastrophical events started to develop by introducing profound fractures within the urban fabric and the whole environmental order of the lagoon. New buildings and urban systems were blindly inculcated upon the delicate and fragile organism of the city without comprehending the new interventions within a global vision of systemic character. But this, we know, was the approach of the Modern age.

Thus, at the turn of the century, large industrial complexes, harbour docks, factories, mills of gigantic size, were erected as clumsy mastodonts in a jewelry gallery. Fortunately, most of them were built in peripheral areas at the very edges of the historical city. The same approach though brought in the 30's and in the immediate post-war decades to a heavy artificialization of a large sector of the lagoon's hinterland (namely Porto Marghera), with consequent alterations of the hydraulic lagunar system, for the implementation of large scale industrial schemes: oil refineries, port terminal, chemical plants, shipyards, etc. ${ }^{8}$

In his analysis of the city recent urban history, Gianni Fabbri observes:

Non vi è dubbio che la costruzione della città industriale costituisca il periodo più critico nella storia di Venezia proprio dal punto di vista della sua capacità di 'autocostruzione' e di salvaguardia dei propri elementi di identità. E se questa situazione di crisi si mantiene entro limiti discreti fino all'inizio di questo secolo, essa si sviluppa con particolare e crescente violenza dagli anni '20 agli anni '60. (...) L' artificialità come alternativa totale al naturalistico, con le sue categorie di certezza dello stato fisico e di finitezza degli assetti, introduce dunque una logica operativa del tutto nuova rispetto all'esperienza storica della costruzione della città e del suo rapporto con l'ambiente lagunare: se è vero che città e laguna definiscono sempre spazi delimitati e dentro ad essi collocano una minuta presenza di elementi (naturali e artificiali) che consentano la misurabilità di ogni luogo, gli impianti portuali e industriali del bordo lagunare scardinano questa regola morfologica e la sostituiscono con lo smisurato, il gigantesco".

The retreat of the industrial wave of the last decades has now left many of these buildings and plants, both on the lagunar city and on the hinterland, as ruins of a storming passage. The re-use of these buildings and the revitalization of their surrounding areas represent a great task and a difficult challenge for the public administration, but also a unique opportunity to re-invent the image of Venice ${ }^{10}$.

Urban planning strategies, feasibility studies, investment prospects, building and planning bye-laws revisions: since the scenario for a considerable re-structuring of the urban

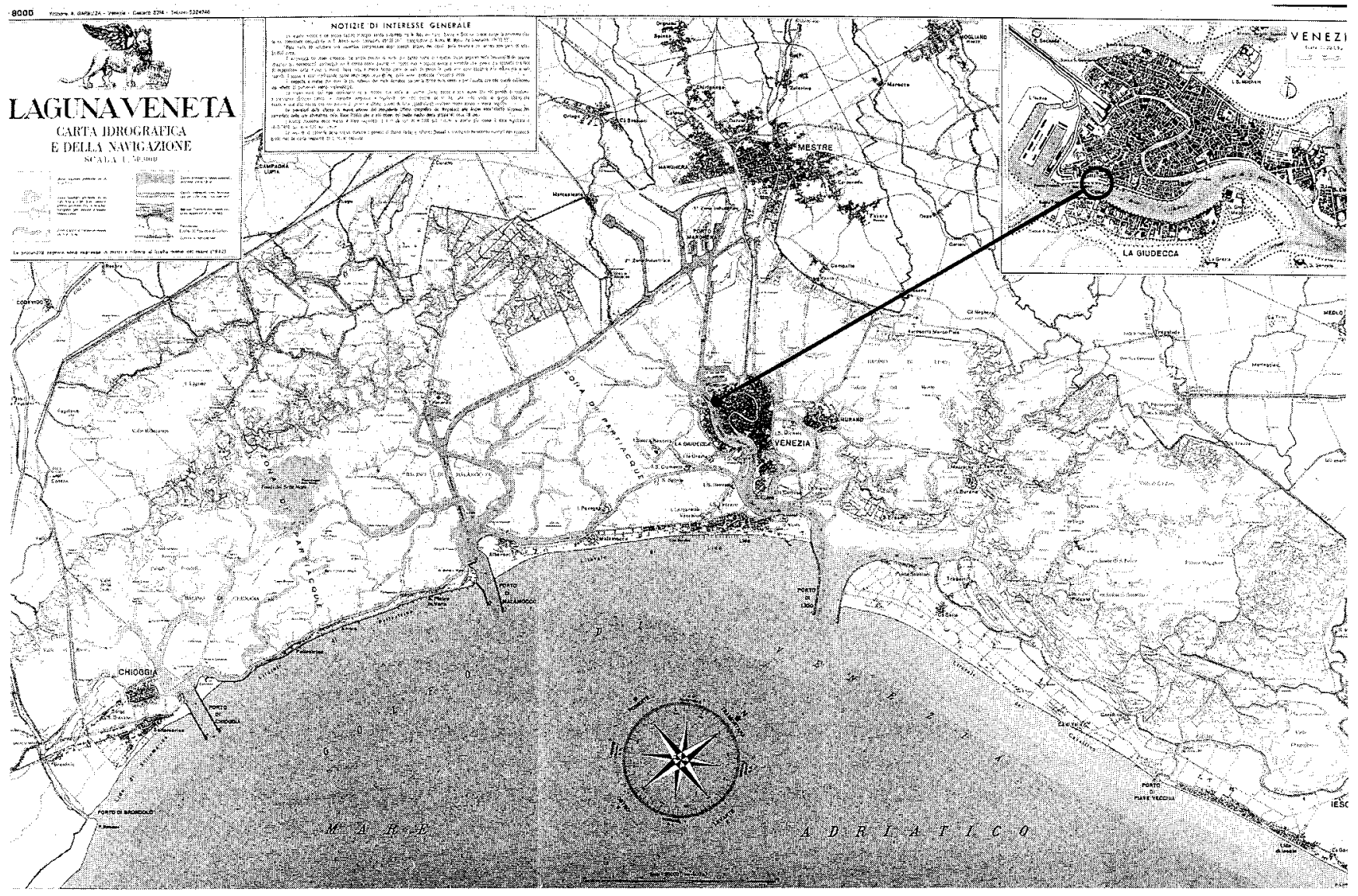

Fig. 1 Map showing the Venice Lagoon and the historical nucleus (upper right) with the site of the project (S. Marta / S. Basilio). 
organism has started to materialize with the taking over of a new administration since 1994, Venice is again not only a case for conservation, but also a matter of design. In this process, architecture in its particular mode of urban design, may play a decisive role in contributing to the definition of the new architecture of the city.

\section{ARCHITECTURE FOUNDS NEW URBAN FORMS}

The areas of S.Marta/S.Basilio, for example, on the southwestern edge of the historical nucleus, are a case in this regard

In these areas, stand a passenger port dock cum shed ("Stazione Marittima"), some warehouses ("Magazzini Ligabue") and other industrial ruins ("Frigorifero Veneziano"), which together sum up to a potentially large building capacity, in the range of $40,000 \mathrm{sqm}^{\prime \prime}$.

Focus of the Administration programmes for these areas is the expansion of the University of Venice facilities presently not really to standard as far as physical support is concerned. Moreover, this policy (encouraging university expansion) is geared to opposing the present trend of making Venice a mono-cultural (touristic) city, by chasing away from the historical centre those non-tourist-oriented activities and those inhabitants who cannot cope with the increasing higher rents and estate prices ${ }^{12}$. However, institutional programming, urban planning and feasibility studies are not able to say what this particular part of the city for example can or should be. Actually, it is through an architectural discourse (reading and projecting) from the point of view of urban design, that is with a strong concern for urban relations, that functional, institutional and planning proposals can further materialize and find a further definition.

A series of academic projects have been therefore developed, both as studio course exercises and as larger departmental research projects within the Istituto Universitario di Architettura.

The major issues which have been dealt with are the following

1) Relations with the major signs of the immediate urban lanscape: the continuous grand "urban theatre" of the Giudecca Island's front, marked by the giant industrial relic of the Mulino Stucky and by the palladian religious complexes (Redentore, Zitelle, S.Giorgio).

2) Relations with the immediate surroundings of the historic fabric, densely built as the rest of the urban organism but also typically marked by religious complexes and campanili.

3) Relations with the paths: the pedestrian large scale long promenade of the Zattere parallel to the Giudecca Canal,

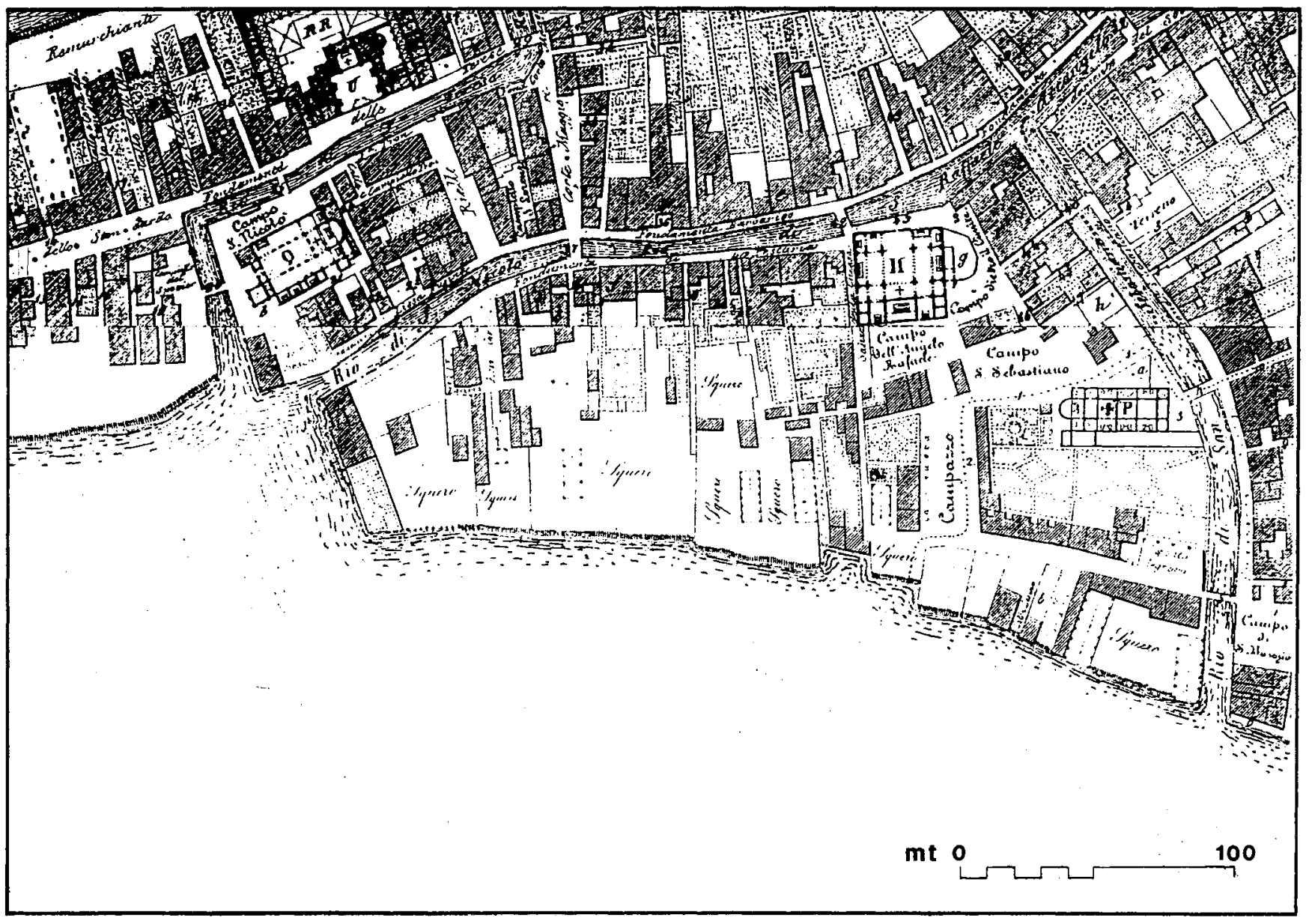

Fig. 2 The area of S. Marta / S. Basilio on the south-western edge of the historical nucleus (map by G.B. Combatti, 1846). 


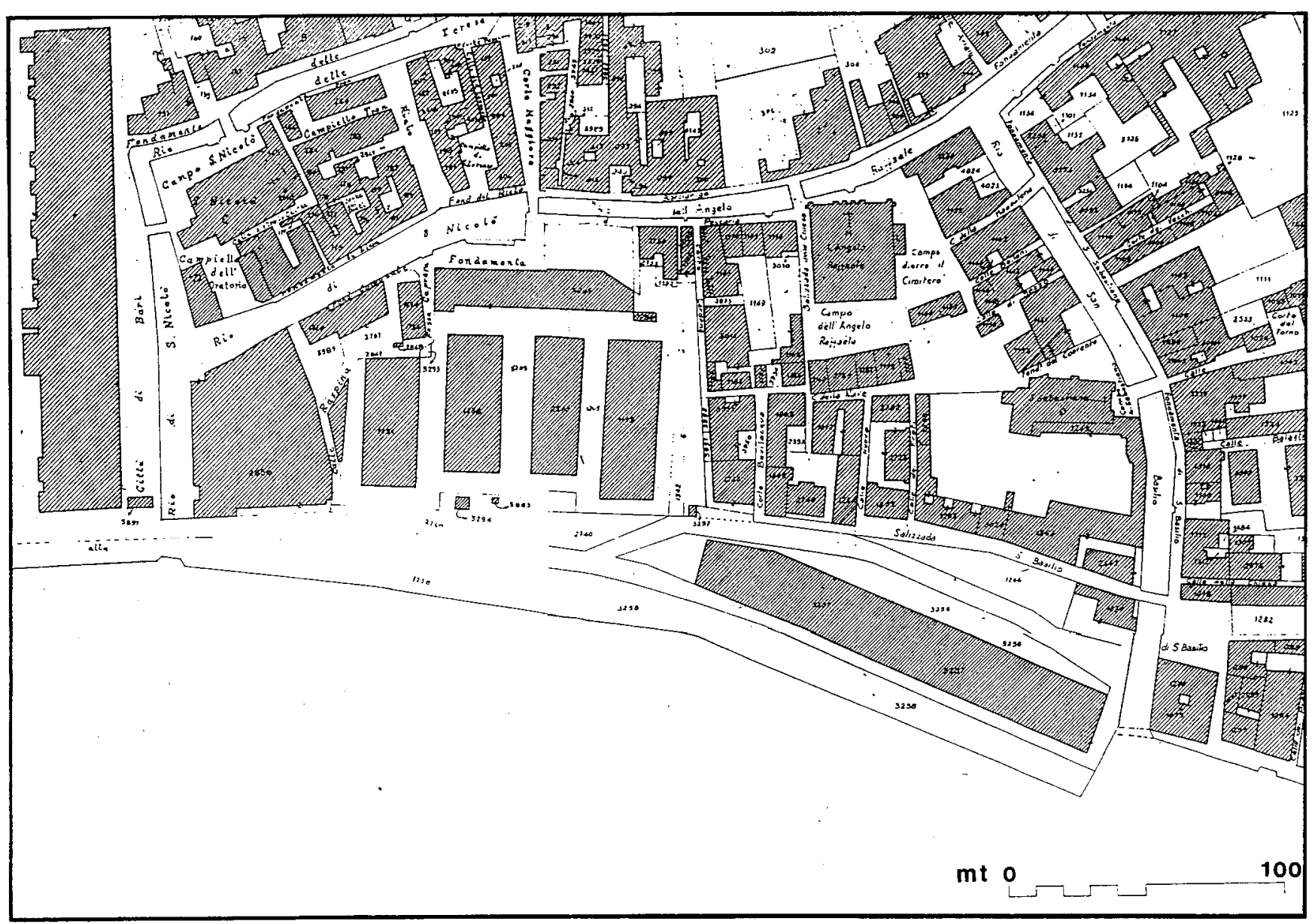

Fig. 3 The area of S. Marta / S. Basilio today.

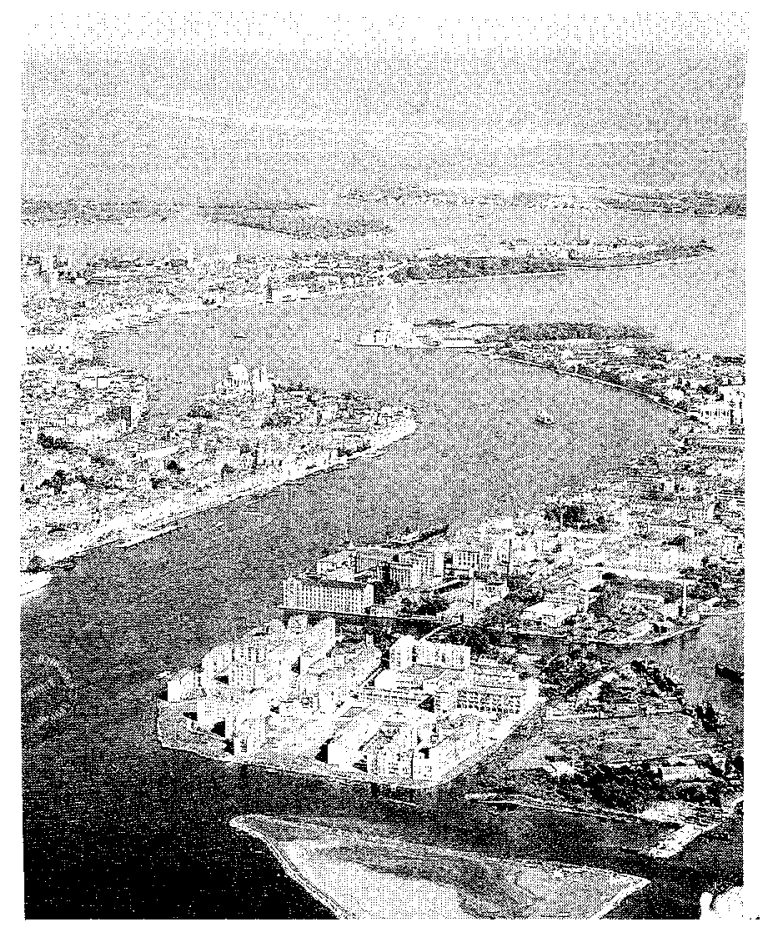

Fig. 4 The Giudecca Canal: the historical nucleus (left), the Giudecca Island (right), the Lagoon's islands and the Lido oulet (background). the narrowcalli perpendicular to it and connecting the areas with the neighbouring historic fabric, but also the "water-highway" of the Giudecca Canal which will become, as a sort of "Canal Grande of the post-industrial city", the main urban axis connecting the revitalized areas of Porto Marghera (a major tertiary pole for research and activities of exellence) with the historic city, the islands of the lagoon and the Lido

4) Relations among the three different areas of S.Marta/ S.Basilio themselves:

- the area of the Stazione Marittima as a first moment of an abrupt change of scale within the urban organism (letting the urban space at the back being just an "urban void"), thus testifying the industrial past, but also trying to continue the long front of the Zattere with a long palazzata and maintaining a primarily residential use

- the area of the former Magazzini Ligabue as a complex of a different nature, more introverted and linked with the immediate surroundings to form a sort of "bazaar for culture" with a system of university facilities

- the area of the former Frigorifero Veneziano as the final accent, the culminating point of a crescendo (for the urban rhythm of this particular part of the city): the site for an institutional (university, but not exclusively) conference centre, "a place for the encounter". 


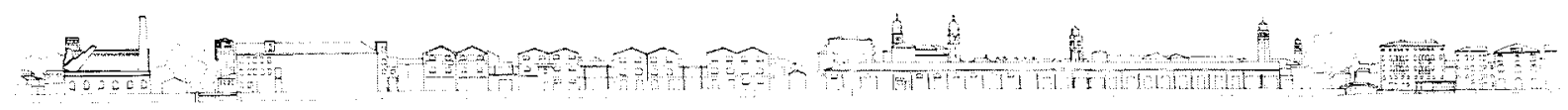

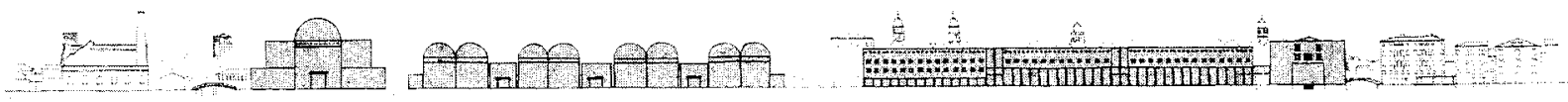

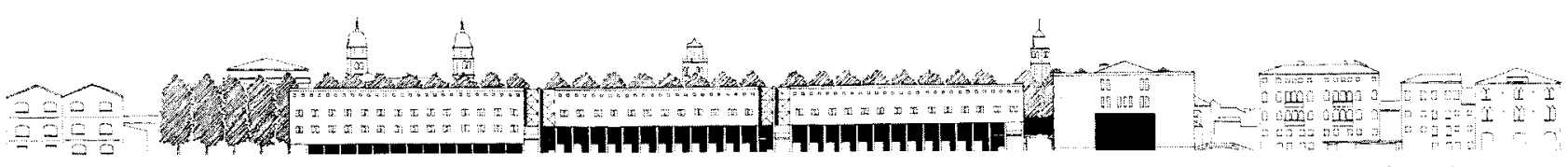

Fig. 5 Profiles: the existing set-up (upper); composition of three proposals (middle); proposal for the Stazione Marittima site (students: Francesca Lagonia, Francesca Rizzani, Igino Zanandrea, tutors: prof. G.B. Fabbri and M. Sabini, 1994)

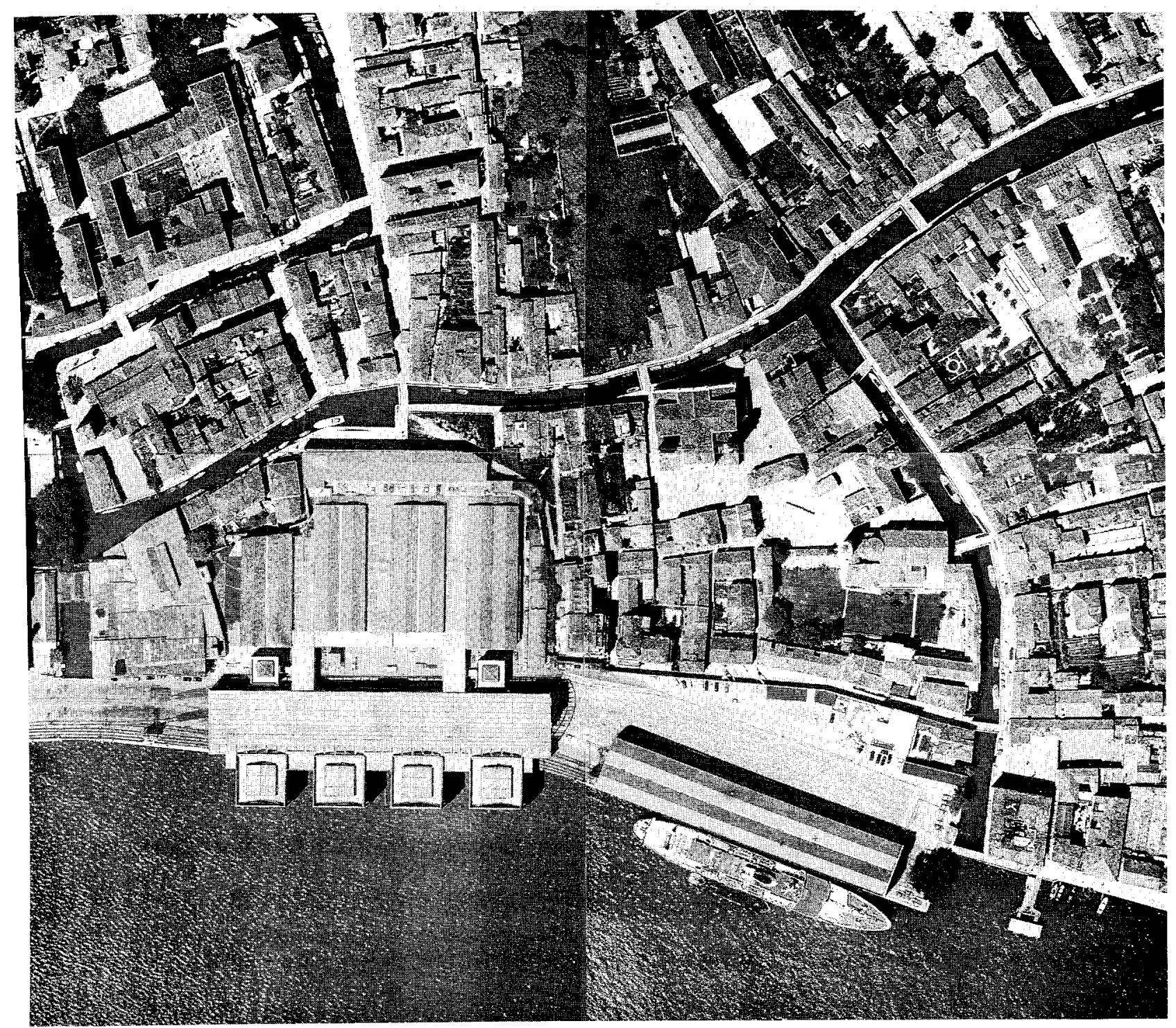

Fig. 6 Aerial view of the proposal (montage for the Magazzini Ligabue site (student: Stefano Medda, tutors: prof. G.B. Fabbri and M. Sabini, 1995). 


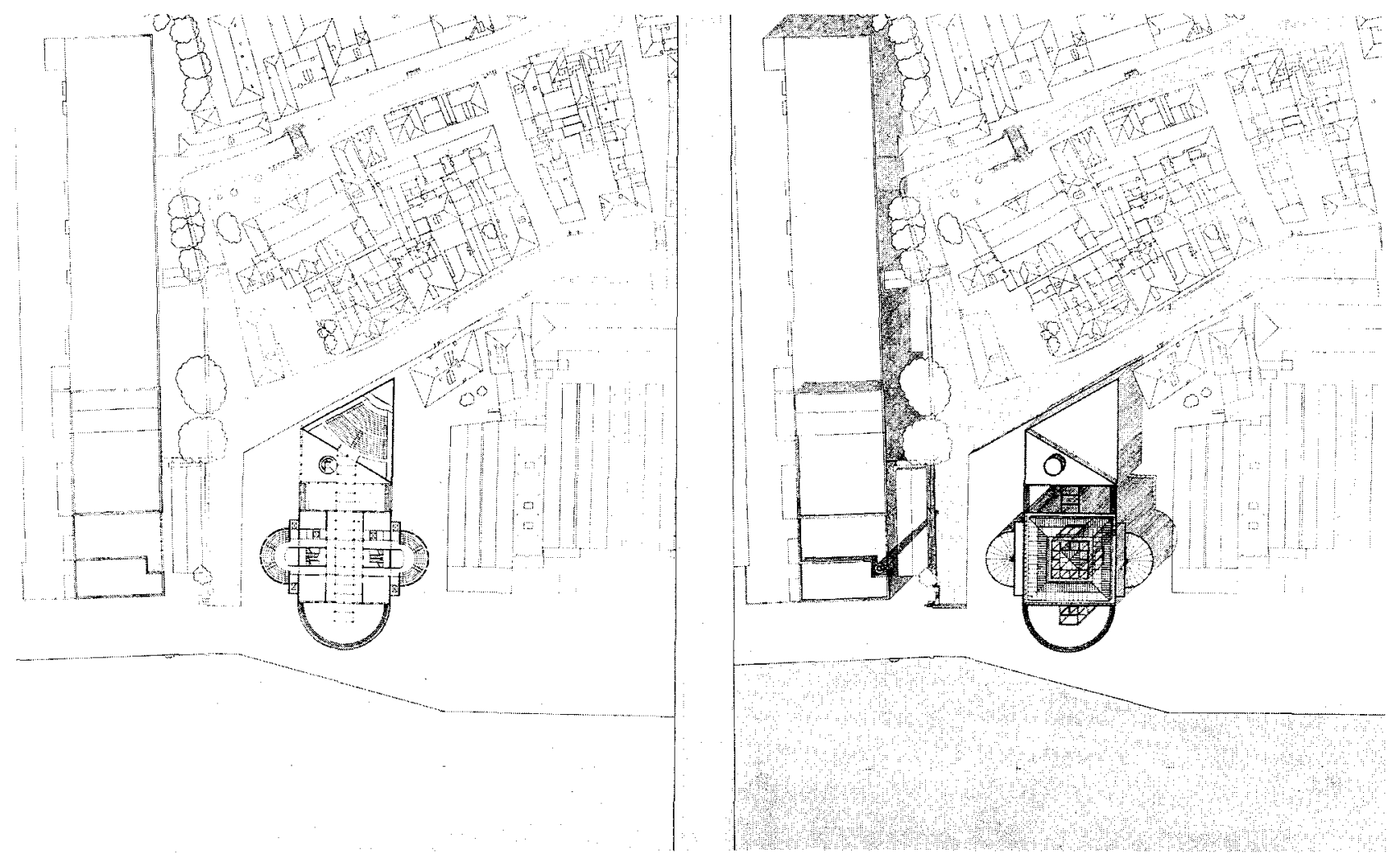

Fig. 7 Proposal for the Frigorifero Veneziano site (student: Alberto Endrigo, tutors: prof. G.B. Fabbri and M. Sabini, 1995)

Therefore, all these relations have been dealt with by addressing the nature of the areas as the place where a different Venice will be displayed, that is the post-industrial city as opposed to the historic nucleus: not omogeneity, continuity, replica of the urban fabric of the past, rather difference, discontinuity, void, change of scale, and yet forms and urban spaces related through the imaginative tool of "memory" to the existing architecture of the city.

By so doing, not only the form and type of the built interventions, but also their quantity, nature and functions may be defined to further support and specify the planning programmes and schemes. In fact, what is here required is primarily to understand what sort of architectural modification of the present urban set-up is appropriate, as the functional needs are not coming out of necessity but out of reasonable opportunities. An appropriate system of urban relations, architecturally defined, for places of new occasions, to the benefit of the city's inhabitants and users.

\section{NOTES}

' Niklas Luhmann, Temporalization of Complexity, in R.F Geyer, J. van der Zouwen, Sociocybernetics, vol. II (Leiden: Nijhoff, 1978): 95-111; Komplexitæt, in Historisches Wörterbuch der Philosophie, vol. IV (Basel-Stuttgart, 1976): 935-41.

2 Michel Foucault, "Des espaces autres", Architecture Mouvement Continuité 5 (1984): 46-49; "Le Language de l'espace" in Critique 203 (1964): 378-82 and "Space Knowledge and Power" in Skyline, March, (1982): 16-20, interview with P. Rabinow. On Foucault's thought, see P. Rabinow (ed.), The Foucault Reader: An Introduction to Foucault's Thought, (London: Penguin, 1984).
${ }^{3}$ Vittorio Gregotti,Questioni di architettura, ed. G. Vragnaz (Torino: Einaudi, 1986): p. 143.

"More interesting is the interpretation of the idea by which space has assumed the form of the relationship between positions, once that the concepts of position and relation are reduced to their material form, through which we receive information on all the other meanings. This does not mean the reduction of everything to a sign, rather the attempt of composing a limited, finite, number of relations and positions within an organizational framework, that is an operational form; it means therefore to imagine environmental transformations as a series of configurations, each of them being rigid. In a sense, it means to return to that idea of space as a hierarchical whole of places".

${ }^{4}$ Vittorio Gregotti, Dentro l'architettura, (Torino: Bollati Boringhieri, 1991), p. 73.

"Every architectural operation is more and more a partial transformation in a given situation: reuse, conservation, but also the new and the different intervention as an act of relationmaking among materials already possessing their own meaning. The urban periphery itself is a place in search of identity through contextual consolidation. 'Design as modification' is also a concept which is reasonably usable whenever one operates on the landscape, for what is still valid of this notion, through a strategy of discrete interventions, minimal modifications, able though of great changes in terms of meanings."

${ }^{5}$ See, H.R. van Gusteren, Constructing a City in Speech: Planning as Political Theory, in B. Barry, Power and Political Theory, (London-New York: John Wiley 1976).

"Denise Scott Brown, Urban Concepts, "AD Profile 83" (London: the Academy Group, 1990), p. 19.

7 The Venice Lagoon is a 58,660 ha salty water basin $(52 \mathrm{~km}$ long and 8 to $14 \mathrm{~km}$ wide) fed by two main rivers, the Brenta on the south and the Sile on the north, with three outlets to the open sea: the "porto" of Chioggia, of Malamocco and of Lido (respectively 500,350 and $800 \mathrm{~m}$ wide). If a $70 \%$ of the basin 
is permanently under water and only $8 \%$ is made of emerging islands, a good $22 \%(27,680$ ha) is submergible (the so-called "living lagoon"), subject to the constantly changing condition of the tide, which has oscillated (according to records taken since 1867) between $-1.21 \mathrm{~m}$ (1934) and + 1.94 (1966) with respect to the average level of the sea.

${ }^{8}$ If the Grand Canal is 50 to $80 \mathrm{~m}$ wide and follows a winding course, and the deepest natural canals in mid-lagoon would not be more than $7 \mathrm{~m}$ deep, artificial canals up to $200 \mathrm{~m}$ wide, with up to $2.5 \mathrm{~km}$ rectilinear stretches, and up to $16 \mathrm{~m}$ deep have been excavated to allow the passage of oil-tankers, therefore severely altering the delicate environmental balance of the lagoon.

Pollution caused by these heavy industrial use of the lagoon's natural set-up is of course another serious problem. Recent reports from "Greenpeace" say that dioxin is present in the Venice Lagoon, even in the Grand Canal at the very heart of the historic nucleus. Of course, the highest rate is traceable near Porto Marghera (from "Il Sole - 24 ore", 4.5.1995).

9 Fabbri, Gianni, "Venezia e il bordo della laguna", in Architetture dei luoghi limite, (Milan: CittàStudi, forthcoming).

"There is no doubt that the building of the industrial town is the most critical period of the Venetian urban history with regard to its own capability of growth and to the conservation of the city identity. If this crisis was kept within acceptable limits till the turn of the century, it develops with particular and increasing violence from the 20 's to the 60 's (...) Artificiality as a total alternative to nature, with its certain cathegories about the definition of the physical set-up, therefore introduces a rationale for action completely new compared to the historical experience of the city building and its relationship with the natural environment: if it is true that the city and the lagoon have always defined areas where tiny (natural and artificial) elements allowed the measurability of each and every place, the port and industrial plants of the lagoon's edge break this morphological order by introducing gigantic, 'out-of-scale' elements".

1n Particularly, the present administration, led by mayor-philosopher Massimo Cacciari, is focussing on the rehabilitation of the Giudecca, the southernmost island of the historical archipelago, with a 240 million US $\$$ scheme, also involving leading architects such as Aldo Rossi, Alvaro Siza, Bernard Huet and Carlo Aymonino. Among the various interventions, all aimed at revitalizing the island's residential milieu, a major 200 million US $\$$ re-use project for some 50,000 sqm of a XIX century mill (Mulino Stucky) has been just launched and mostly privately financed.

$"$ C. Magnani, F. Messina, F. Pittaluga, M. Sabini, "Stima del fabbisogno di dotazioni per attrezzature universitarie a Venezia e Mestre", paper, May 1994, research project: "Venezia, città degli studi", directed by prof. G. Fabbri, Dipartimento di Progettazione Architettonica, Istituto Universitario di Architettura di Venezia.

12 Historic Venice accounts now for only 72,000 inhabitants (out of 300,000 for the whole municipality with the mainland), while even until 1950 up to 184,000 people were living there. In 1564, during the glorious times of the Venetian Republic of the Serenissima, 160,000 inhabitants were already registered. It has been reckoned that, at the present migrating rate, by the year 2015 Venice will be a village of 25,000 inhabitants. 